\title{
EFFECT OF LOW TEMPERATURE ON GROWTH AND DEVELOPMENT OF WHEAT AND RESPONSE MECHANISM
}

\author{
Qiaoyan Chen ${ }^{1}$, Wenhui Wie ${ }^{1}$, Kandyba Nataliya ${ }^{2}$ \\ ${ }^{1}$ Henan Institute of Science and Technology, Chinese People's Republic \\ ${ }^{2}$ Sumy National Agrarian University, Ukraine
}

Low temperature is one of the important environmental factors affecting plant growth and development and yield formation. Wheat is an important food crop in the world, and the annual low temperature causes huge losses to plant yield. Therefore, cold resistance has always been an important research field in agricultural production and breeding. Wheat is mainly divided into winter frost damage, early spring frost damage, low temperature freezing damage, etc. The effects of freezing damage on wheat yield in different periods are different. This paper mainly introduces the influence of low temperature on its morphological development and yield formation, as well as the research progress in physiological, biochemical and molecular biology. Finally, it points out the shortcomings in the research and looks forward to the future research direction of low temperature.

\section{Key words: low temperature, Morphological development, physiological, biochemical and molecular biology}

Wheat is one of the world's major food crops, and about $40 \%$ of the world's population is dominated by wheat [1]. Wheat grows in a complex and variable environment and is affected by biotic and abiotic stresses. It is estimated that the annual loss of bac-related losses such as pests and diseases in the world's crops is nearly $20 \%$, and the yields associated with abiotic stress are reached. 50\%. Therefore, abiotic stress (mainly including drought, salinity, extreme temperature) is the leading cause of the reduction of global food crops, resulting in a large number of important food crops reduced production [2]. Among them, low temperature freezing is a serious natural disaster in agricultural production, and it is also a regional and seasonal limiting factor for some crops. For every $1^{\circ} \mathrm{C}$ reduction in temperature in the world, food production will be reduced by $40 \%$, and the annual economic losses caused by freezing damage in the world amount to hundreds of billions of dollars [3,4]. The cold resistance of plants is controlled by the genes of their own phylogeny, and at the same time by the physiological and ecological factors in the development of individuals. Therefore, breeding breeding varieties with strong cold resistance, establishing high-yield cultivation techniques for good varieties and good techniques, and improving the comprehensive cold resistance of wheat are the urgent problems to be solved in the safe and efficient cultivation of wheat [5]. With the development of molecular biology, genetic engineering is used to transform the cold resistance of wheat, and combined with the study of cold resistance physiology, revealing the cold resistance mechanism of wheat from the level of genes and expression products provides a theoretical basis for wheat genetic breeding.

Effects of low temperature on the morphology and yield formation of wheat plants. The cold resistance of wheat is determined by its own genetic factors and the external environment. When the low temperature exceeds its tolerance range, the external morphology and internal structure of wheat will die and die. Low temperature stress in different growth stages has different effects on wheat yield [6]. The seasonal freezing damage is firstly caused by frost damage of the leaves, and the external symptoms are obvious. When the freezing damage is serious, dead and dead seedlings appear. The order of freezing and freezing of tillers is first small sputum, followed by large stems, then main stems, and finally frozen joints. The early spring frost damage is

(c) Chen Qiaoyan, Wie Wenhui, Nataliya Kandyba. 2020.

ISSN 1026-9959. Селекція і насінництво. 20120. Випуск 118. 
mainly manifested in the main stem, large tillers and young ears are frozen, the leaves are slightly dry, and the external symptoms are not obvious. With the advancement of wheat ear development, the cold-resistant ability of young spikes gradually decreased. The interval from the drug to the booting stage was a low-temperature sensitive period, and the low temperature seriously affected the number of spikes and the number of grains per panicle. The low-temperature pollen activity decreased, the number of degenerated spikelets increased, the number of panicles decreased, the panicle length became shorter, the plant height became shorter, and the decrease in panicle number was the main reason for the decrease in yield, followed by the decrease in panicle number. Low temperature stress in the drug compartment, meiosis and flowering period accelerated the premature senescence of the flag leaf after flowering, the production of photosynthetic material decreased, and the granulated grain filling material decreased, which seriously affected the grain number and grain weight. The application of urea to restore fertilizer after low temperature stress in the drug compartment mainly promoted the increase of the number of grains per panicle and the number of panicles. The application of urea to restore the fertilizer after meiosis during low temperature stress mainly promoted the increase of grain number per grain and grain weight, thus recovering the yield loss [7]. After low temperature stress at jointing stage, the more the yield decreased with the increase of stress time, the main reason for the decrease in yield was the number of spikes and the number of grains per panicle [8].

Effect of low temperature on physiology and biochemistry of wheat. After suffering from low temperature stress, wheat not only has morphological changes, but also a series of complex physiological changes in the plant, resulting in many specific proteins, osmotic adjustment substances and various antioxidant enzymes that can resist low temperature, in order to maintain the normal physiological metabolism of wheat activity. The cell membrane is the primary site where the plant senses the low temperature signal, and the interface between the cell and the external environment. The structure of the cell membrane is a kind of dynamic equilibrium system. When the plant cells are subjected to low temperature stress to reach a certain phase transition temperature, the membrane lipid will change from a fluid liquid phase to a crystalline solid phase, which will increase the membrane permeability and extracellular fluid permeation. The fatty acid chains change from disordered to ordered, and the electrolyte and soluble substances in the cells leak out to the outside of the membrane, causing the ion balance inside and outside the cell to be destroyed, the enzymatic reaction to be dysregulated, and the metabolic disorder eventually leading to cell death. In normal metabolism, the production and elimination of reactive oxygen species in plants are in equilibrium. Under low temperature stress, the enzymatic defense system and non-enzymatic defense system in the free radical scavenging system of plants will strengthen and resist to some extent. Clears the damage of reactive oxygen species to maintain normal physiological metabolic activity [9].The low temperature causes the intercellular concentration to decrease, the osmotic pressure increases, and the protoplast solution penetrates into the ice from the cell to the outside of the cell to inactivate the dehydration. The key to osmotic adjustment is that the cells actively accumulate solute and reduce the cell osmotic potential [10]. Free proline increases the soluble protein content, increases the hydrophilic area of the protein, binds more water, relieves the effect of low temperature on the cells, reduces the possibility of protoplasts causing plant death due to low temperature icing, and maintains normal cell membrane material transport and cells. Internal and external osmotic adjustment to improve cold resistance of crops [11]. Li Chunyan et al. found that the increase of ABA content and the decrease of GA3 content in the low temperature treatment test from the drug partition to the flowering stage were beneficial to increase the ability of wheat to resist low temperature stress [12].

The study of molecular biology of wheat cold resistance. With the development of molecular biology, the research focus of plant cold resistance mechanism has shifted from physiological and biochemical level to molecular level. Cold resistance is a quantitative trait regulated by multiple genes. According to the function of its products, it is mainly divided into regulatory genes and protective genes. The products of regulatory genes regulate the signaling and the expression of protective genes. For example, transcription factors, protein kinases, and protective genes directly play a role in cold resistance. Such as antifreeze protein, chaperone protein [13]. At 
low temperature stress, plants first experience low-temperature signals, followed by a series of physiological and biochemical reactions, and then regulate gene expression, and one of the conduction systems is a signal transduction pathway regulated by transcription factors, which can be summarized as: CBF transcription factor $\rightarrow$ Control the cold-induced gene containing CRT/DRE motif $\rightarrow$ regulate the expression of COR gene $\rightarrow$ Increase the cold resistance of plants; it is generally believed that the membrane lipid unsaturated fatty acid is related to the cold resistance of plants, and its content will increase the membrane lipid phase. The temperature is lowered, which increases the fluidity of the membrane and ultimately improves the cold resistance of the plant [14]. Lu Yan studies showed that the gene expression levels of transcription factor genes (Tab ZIP1, Ta Wabi5, Ta MYB1, Ta MYB80, Ta NAC2 and Ta WRKY80) reached the highest at -10 ${ }^{\circ} \mathrm{C}$, indicating that the temperature at $-10 \mathrm{C}$ is cold stress in Dn1. Related transcription factor genes respond to temperature critical points of low temperature regulation [15]. The rice zaponin b ZIP73Jap protein interacts with another b ZIP protein b ZIP71 to regulate the levels of phytohormone $\mathrm{ABA}$ and reactive oxygen species (ROS) in rice, thereby increasing the tolerance of rice to low temperature [16]. Zhao Hu et al. showed that Ta PDF1.2 is a JA-responsive gene, and its increased expression indicates JA accumulation; Ta COI1 and Ta MYC2 are key genes in JA signal transduction pathway, and the increase in expression will initiate downstream cold-induced genes. Transcription, improving the cold resistance of plants [17]. Lu qiuwei studied that mi R398 and the complex biological regulatory network between lncRNA and the target gene CSD1, mi R398 can regulate its target gene CSD1 to initiate a cold-resistant response, and is competitively bound by lncRNA to regulate the expression of the target gene CSD1. In turn, it affects the cold resistance of Dongnongdongmai 1 [18].

Prospect. Improving the cold resistance of wheat is of great significance for increasing food production. In terms of research methods, many studies have used artificial climate chambers to simulate low temperature stress. Although this method can well indicate the influence of single stress on plants, it has certain limitations on field crop breeding, and sometimes even control experiments and Daejeon. The results of the trials are contradictory, so future studies on the cold resistance of plants should be carried out in conjunction with the Daejeon experiment [19, 20]. Low temperature is a trait controlled and regulated by multiple genes. At present, most studies focus on a single gene, and in the future research, drought, sputum, saline and alkali should be combined with cold resistance. At the molecular level, the resistance to low temperature resistance in wheat is still very weak, mainly physiological and biochemical research, which has not been verified by molecular level; the signal transduction mechanism and gene regulation expression of low temperature related proteins are still unclear, and the current gene is still used. The study of regulation to explain the physiological mechanisms of cold resistance is not extensive. With the development of molecular biology technology, the emergence of high-throughput sequencing technology of wheat genome, the extensive application of proteomics and metabolomics technology, multi-disciplinary cross-fusion makes it possible to explain the mechanism of resistance to cold spring from the perspective of system biology. The cold-tolerant gene uses genetic engineering to improve the transformation and expression of cold-resistant genes. At the same time, it is necessary to strengthen the collection and identification of cold-resistant wheat germplasm resources and provide materials for traditional breeding. The effective combination of molecular breeding and conventional breeding to carry out wheat stress-resistant breeding and breeding new varieties of cold-tolerant spring wheat is a key area to be strengthened in the future.

\section{References}

1. He Zhonghu, Zhuang Qiaosheng, Cheng Shunhe, et al. China's wheat industry development and scientific and technological progress. Journal of Agronomy, 2018.

2. Mou Yongchao. Expression analysis of Three Genes from SSH Library constructed using tillering nodes of Dongnongdongmai 1 under Low Temperature Stress [dissertation ]. Northeast Agricultural University, 2011.

3. Hale MG, Orcutt DM. The physiology of plants under stress. New York: J. Wiley, 1996. 
4. Steponkus PL, Webb MS. Freeze-induced dehydration and membrane destabilization in plants. Water and Life. 1992.

5. Yi Ying, Guo Zhifu, Zhang Yulong, et al. Research status and prospect of winter wheat frost resistance. Hubei Agricultural Science, 2013; 52(12).

6. Liu Liwei. Effects of low temperature at anther connective formation, meiosis and anthesis stages on grain yield in wheat and remedial techniques. 2016.

7. Yang Chunling, Song Zhijun, Chen Yuxiang, et al. Study on mechanism of cold resistance in wheat. Shanxi Agricultural University. 2008; (1).

8. $\mathrm{Xv}$ Wen, Yang Jing, Deng Lele, et al. Effect of yield of and its mitigation measures in Yangmai 16 under low temperature stress. Journal of Nuclear Agriculture. 2014; 9(2).

9. Xie Dongwei. Analysis on gene expression profile and trehalose gene familyin winter wheat under low temperature. Northeast Agricultural University. 2014.

10. Chen Ruoli, Zhang Dongzhi, Chen Feng, et al. The importance of adjusting wheat variety allocation based on freezing injury wheat spike in 2013. Anhui Agricultural Sciences. 2013; 41(15).

11. Zhang Lei, Li Guoling, Zhang Jianzhou, et al. Effects of low temperature stress on physiological characters and yield of two wheat varieties at jointing stage. Henan of Agricultural Sciences. 2017; (11):19-24.

12. Li Chun-yan, Li Dong-sheng, Song Sen-nan, et al. Research progress on physiologicalmechanism and prevention approaches of cold injury in wheat. Journal of Wheat Crops. 2010; 30(6):1175-1179.

13. Bin Zhang. Cultivar technology Selection and analysis of cold resistance molecular mechanism of winter wheat in mixed sowing winter-spring wheat zone in Shanxi [dissertation ]. 2015.

14. Lin Mao, Yan Haixia, Gui Shunzhao, et al. CBF transcription factors and its application in genetic engineering. Guangxi Agricultural Sciences. 2008; 39(1): 21-25.

15. Lv Yan, Cang Jing, Lu Qiuwei, et al. Bioinformatics analysis and effects of low temperature and ABA on TabZIP1 expression pattern of wheat Dongnongdongmai 1. Journal of Wheat Crops. 2017; 37(1): 22-29.

16. Liu Citao, Qu Shujun, Chu Chengcai. bZIP73: Key genes affecting the tolerance of japonica rice to low temperature. Genetics; 40(9).

17. Zhao Hu. Effect of MeJA on cold-resistance and cold stress of TaCOI1/TaMYC2 gene in winter wheat [D]. 2018.

18. Lu Qiuwei. Screening cold-resistant lncRNA of winter wheat and through interaction with tae-miR398 in response to cold stress [dissertation ]. 2018.

19. Płażek A, Hura K, Żur I, et al. Relationship between frost tolerance and cold-induced resistance of spring barley, meadow fescue and winter oilseed rape to fungal pathogens. Journal of Agronomy \& Crop Science. 2010; 189(5): 333-340.

20. Ensminger I, Busch F, Huner NPA. Photostasis and cold acclimation: sensing low temperature through photosynthesis. Physiologia Plantarum. 2010; 126(1): 28-44.

\title{
EFFECT OF LOW TEMPERATURE ON GROWTH AND DEVELOPMENT OF WHEAT AND RESPONSE MECHANISM
}

\author{
Qiaoyan Chen ${ }^{1}$, Wenhui Wie ${ }^{1}$, Kandyba Nataliya ${ }^{2}$ \\ ${ }^{1}$ Henan Institute of Science and Technology, Chinese People's Republic \\ ${ }^{2}$ Sumy National Agrarian University, Ukraine
}

Low temperature is one of the important environmental factors affecting plant growth and development and yield formation. Wheat is an important food crop in the world, and the annual low temperature causes huge losses to plant yield. Therefore, cold resistance has always been an 
important research field in agricultural production and breeding. Wheat is mainly divided into winter frost damage, early spring frost damage, low temperature freezing damage, etc. The effects of freezing damage on wheat yield in different periods are different. This paper mainly introduces the influence of low temperature on its morphological development and yield formation, as well as the research progress in physiological, biochemical and molecular biology. Finally, it points out the shortcomings in the research and looks forward to the future research direction of low temperature.

Key words: low temperature, morphological development, physiological, biochemical and molecular biology

\section{ВПЛИВ НИЗЬКОЇ ТЕМПЕРАТУРИ НА РІСТ І РОЗВИТОК ПШЕНИЦІ І МЕХАНІЗМ РЕАГУВАННЯ}

Цяоянь Чень ${ }^{1}$, Веньхуй $\mathrm{Bi}^{1}$, Кандиба Наталія ${ }^{2}$

${ }^{1}$ Хенанський інститут науки і технологій, Китайська Народна Республіка

${ }^{2}$ Сумський національний аграрний університет, Україна

Низька температура - один із важливих факторів навколишнього середовища, що впливає на ріст та розвиток рослин та формування врожаю. Пшениця є важливою харчовою культурою у світі, а щорічна низька температура спричиняе величезні втрати врожаю рослин. Тому холодостійкість завжди була важливим напрямом досліджень у сільськогосподарському виробництві та селекції. Пшениця в основному поділяється на пошкодження зимовими морозами, пошкодження раннього весняного морозу, пошкодження від низьких температур при заморожуванні тощо. Ця робота представляє результат впливу низької температури на морфологічний розвиток та формування врожаю, а також прогрес досліджень у фізіологічній, біохімічній та молекулярній біології.

Ключові слова: низька температура, морфологічний розвиток, фізіологічна, біохімічна та молекулярна біологія

\section{ВЛИЯНИЕ НИЗКОЙ ТЕМПЕРАТУРЫ НА РОСТ И РАЗВИТИЕ ПШЕНИЦЫ И МЕХАНИЗМ РЕАГИРОВАНИЯ}

Цяоянь Чень ${ }^{1}$, Веньхуй Ви ${ }^{1}$, Кандыба Наталия ${ }^{2}$

${ }^{1}$ Хенанський институт науки и технологий, Китайская Народная Республика

${ }^{2}$ Сумской национальный аграрный университет, Украина

Низкая температура - один из важных факторов окружающей среды, влияющая на рост и развитие растений и формирование урожая. Пшеница является важной пищевой культурой в мире, а ежегодная низкая температура вызывает огромные потери урожая растений. Поэтому холодостойкость всегда была важным направлением исследований в сельскохозяйственном производстве и селекции. Пшеница в основном делится на повреждение зимними морозами, повреждения раннего весеннего мороза, повреждения при низких температурах при замораживании и другое. Эта работа представляет результаты влияния низкой температуры на ее морфологическое развитие и формирование урожая, а также прогресс исследований в физиологической, биохимической и молекулярной биологии.

Ключевые слова: низкая температура, морфологическое развитие, физиологическая, биохимическая и молекулярная биология 